\title{
Changes in benthic community structure due to clam dredging on the Algarve coast and the importance of seasonal analysis
}

\author{
Filipe Alves**, Luís Chícharo*, António Nogueira ${ }^{\dagger}$ and João Regala*
}

\begin{abstract}
Patterns in community structure of meiofauna and macrofauna in relation to Portuguese clam dredging were compared during a 2-y-period off Lagos and Vilamoura, south Portugal. SCUBA divers randomly sampled corer and quadrat samples before and immediately after simulating commercial dredge fishery. Univariate measures (abundance, number of taxa, evenness, diversity and biomass) and multivariate analyses (Cluster, MDS and SIMPER) revealed changes in the meio- and macro-benthic community structure caused by dredge disturbance (short-term effects), with a general decrease in all measures. Macrofauna were found to be more sensitive to dredge disturbance, and aggressive predatory behaviour was observed after disturbance in the continuously dredged area. Nevertheless, higher significant natural changes were found between seasonal periods, indicating that dredging may only cause a small-scale and short-term impact.
\end{abstract}

\section{INTRODUCTION}

Commercial fishing can affect benthic communities by directly removing and/or injuring surface-living organisms in the path of the equipment, or by digging into the sediment and thus affecting both infauna and the epibenthos (Bergman \& Hup, 1992; Tuck et al., 1998). The environmental effects of shellfish dredging have thus received particular recent attention worldwide (see Caddy, 1968, 1973; Meyer et al., 1981; Hall et al., 1990; Kaiser \& Spencer, 1996; Jennings et al., 2001).

In Portugal, bivalve dredging has played important economic and social roles since 1969. Today, the industry targets the species Spisula solida, Donax trunculus, Venus striatula, Pharus legumen and Ensis siliqua (Gaspar, 1996). Bivalves are caught with a dredge that can penetrate into the sediment up to $50 \mathrm{~cm}$, depending on the target species and sediment type. However, only recently has concern developed about the possible impact of dredging on the fauna of Portuguese waters, as shown by studies of damage to E. siliqua (Gaspar et al., 1994, 1998, 2001), predatory aggregation (Chícharo et al., 2003) and diversity along dredge track sections (Chícharo et al., 2002a).

In general, dredges are designed to dig into the surface of the sediment and can cause extensive mortality to the benthic organisms, particularly in areas with an established sessile epifauna (Holme, 1983; Robinson \& Rowell, 1990; Kaiser \& Spencer, 1994). The dredge fishery's impact upon benthic communities is responsible for changes in biodiversity, taxonomic composition, feeding habits and community structure (Currie \& Parry, 1996, 1999; Jennings et al., 2001). These changes in the community structure caused by fishing disturbance can be detected on a short-term scale (de Groot, 1984; Currie \&
Parry, 1996; Kaiser \& Spencer, 1996; Pranovi \& Giovanardi, 2000). Such studies can provide reliable results; however, long-term effects are more difficult to evaluate and are consequently scarce in the literature (Witbaard \& Klein, 1994; Tuck et al., 1998).

The analysis of seasonal changes in benthic assemblages is also of major importance in ecological studies. Seasonal variations among several marine coastal benthic communities of the north-east Atlantic have been studied in the North Sea (Buhl-Jensen \& Fossa, 1991; Hamerlynck \& Mees, 1991), the Baltic Sea (Ólafsson \& Elmgren, 1997), the Celtic Sea (Bottrell \& Robins, 1984), the Bay of Biscay (Sorbe, 1999) and the west coast of Portugal (Ría de Aveiro; see Cunha et al., 1999). However, there has been no analysis of the seasonal variations of the meioand macro-fauna benthic communities of the south Portuguese soft-bottom coastal waters.

The results presented here concern sampling in two areas of the Algarve coast during a 2-y-period, to investigate the short-term changes in the meiofauna and macrofauna benthic communities structure caused by clam dredging, and to compare them within seasonal variations. The results are discussed in relation to overall fishing impact for the areas, and highlight the importance of seasonal fluctuations for an accurate assessment of short-term changes.

\section{MATERIALS AND METHODS}

$$
\text { Sampling design }
$$

The research vessel 'Donax' undertook dredging at a site 7-9 m deep (plummet data) off Falésia Beach, Vilamoura, and off Lagos Bay, both in the Algarve region of South Portugal (Figure 1) in April and October 1999, and in 


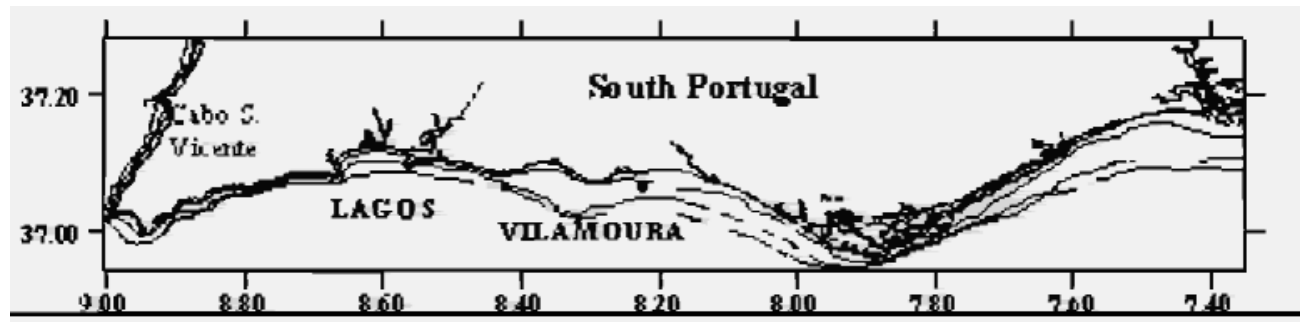

Figure 1. The South Portugal (Algarve) coast, showing location of the studied areas: Lagos and Vilamoura (according to Chícharo et al., 2002b).

Table 1. Significance levels from two-way ANOVA tests for differences in various univariate measures of community structure (see text) between: (1) before/after dredging; (2) seasons; and (3) interaction between both, for meiofauna and macrofauna at Lagos and Vilamoura.

\begin{tabular}{|c|c|c|c|c|c|c|c|c|c|c|c|c|}
\hline \multirow{3}{*}{$\begin{array}{l}\text { Univariate } \\
\text { measure }\end{array}$} & \multicolumn{6}{|c|}{ Meiofauna } & \multicolumn{6}{|c|}{ Macrofauna } \\
\hline & \multicolumn{3}{|c|}{ Lagos } & \multicolumn{3}{|c|}{ Vilamoura } & \multicolumn{3}{|c|}{ Lagos } & \multicolumn{3}{|c|}{ Vilamoura } \\
\hline & 1 & 2 & $1 \times 2$ & 1 & 2 & $1 \times 2$ & 1 & 2 & $1 \times 2$ & 1 & 2 & $1 \times 2$ \\
\hline$A(\sqrt{ } \sqrt{ })$ & $<0.01$ & $<0.01$ & $<0.01$ & 0.07 & $<0.01$ & 0.05 & $<0.01$ & $<0.01$ & $<0.01$ & 0.43 & $<0.01$ & 0.09 \\
\hline$T(\sqrt{ } \sqrt{ })$ & $<0.01$ & 0.04 & $<0.01$ & $<0.01$ & 0.12 & 0.92 & $<0.01$ & $<0.01$ & $<0.01$ & 0.87 & $<0.01$ & 0.02 \\
\hline 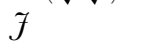 & 0.06 & $<0.01$ & 0.46 & 0.12 & $<0.01$ & 0.13 & 0.04 & $<0.01$ & 0.16 & 0.17 & 0.6 & 0.31 \\
\hline$H^{\prime}$ & 0.19 & $<0.01$ & 0.76 & $<0.01$ & 0.04 & 0.08 & $<0.01$ & $<0.01$ & 0.12 & 0.56 & $<0.01$ & $<0.01$ \\
\hline$B(\sqrt{ } \sqrt{ })$ & $<0.01$ & $<0.01$ & 0.66 & 0.5 & $<0.01$ & 0.24 & 0.37 & $<0.01$ & 0.34 & 0.66 & $<0.01$ & 0.05 \\
\hline
\end{tabular}

Table 2. Mean and standard deviations of the meiofauna abundance $\left(\mathrm{m}^{2}\right)$ before and after dredging, at Lagos and Vilamoura, using data from all seasonal periods. $n$. id., non identified. Blanks represent zeros.

\begin{tabular}{|c|c|c|c|c|}
\hline \multirow[b]{2}{*}{ Meiofauna taxa } & \multicolumn{2}{|c|}{ Lagos } & \multicolumn{2}{|c|}{ Vilamoura } \\
\hline & Before & After & Before & After \\
\hline Phylum NEMATODA & $293730 \pm 263584$ & $127677 \pm 99623$ & $122450 \pm 125925$ & $84000 \pm 86434$ \\
\hline Class TURBELLARIA & $29230 \pm 175552$ & $435 \pm 861$ & $450 \pm 605$ & $219 \pm 608$ \\
\hline Class OLIGOCHAETA & $11932 \pm 34576$ & $2565 \pm 6232$ & $300 \pm 571$ & $250 \pm 718$ \\
\hline Order COPEPODA & $9378 \pm 13223$ & $5516 \pm 12117$ & $18600 \pm 22993$ & $12031 \pm 25555$ \\
\hline Class POLYCHAETA & $6554 \pm 6194$ & $3694 \pm 3405$ & $2400 \pm 6012$ & $844 \pm 1568$ \\
\hline Order ISOPODA & $1770 \pm 8921$ & $65 \pm 248$ & $300 \pm 571$ & $94 \pm 390$ \\
\hline Phylum NEMERTINEA & $1203 \pm 3351$ & $1645 \pm 8667$ & $1400 \pm 2741$ & $969 \pm 2845$ \\
\hline Class BIVALVIA & $1122 \pm 3515$ & $1113 \pm 3398$ & $400 \pm 754$ & $1594 \pm 3826$ \\
\hline Order AMPHIPODA & $797 \pm 3701$ & $210 \pm 547$ & $100 \pm 308$ & $31 \pm 177$ \\
\hline Order OSTRACODA & $608 \pm 1004$ & $242 \pm 645$ & $550 \pm 1395$ & $406 \pm 798$ \\
\hline Order TANAIDACEA & $446 \pm 846$ & $484 \pm 1036$ & & \\
\hline Phylum TARDIGRADA & $243 \pm 857$ & $32 \pm 254$ & & \\
\hline Phylum GNIDARIA & $189 \pm 734$ & $16 \pm 127$ & & $31 \pm 177$ \\
\hline Class GASTROPODA & $135 \pm 448$ & & & $31 \pm 177$ \\
\hline Ordern CUMACEA & $68 \pm 302$ & $48 \pm 216$ & $50 \pm 224$ & $63 \pm 246$ \\
\hline Class HALAGAROIDEA & $68 \pm 253$ & & $950 \pm 1356$ & $469 \pm 915$ \\
\hline Order CLADOCERA & & $16 \pm 127$ & & \\
\hline Phylum SIPUNCULO & & & & $250 \pm 1107$ \\
\hline n. id. Taxa & $176 \pm 866$ & $97 \pm 534$ & $100 \pm 308$ & $31 \pm 177$ \\
\hline
\end{tabular}

July and October 2000. On each occasion, a commercial Portuguese clam dredge (Figure 2) was used. The dredge was towed for $1 \mathrm{~min}$ at a mean speed of 2 knots; this fishing speed is similar to that used by commercial dredge fleets. Our survey was done with the type of dredge used by commercial fishers for the clam Spisula solida. The dredge is a large, heavy iron structure, with a $25-\mathrm{mm}$ mesh net bag and a toothed lower bar at the mouth. The gear's mouth can be up to $100 \mathrm{~cm}$ wide, with teeth up to $10 \mathrm{~cm}$ in length, which act as a rake when the dredge is dragged over the sea bottom (Gaspar, 1996).

Six replicate quadrats $\left(0.0625 \mathrm{~m}^{2} \times 0.15 \mathrm{~m}\right.$ depth $)$ for macrofauna and four replicate corers $\left(0.001 \mathrm{~m}^{2} \times 0.15 \mathrm{~m}\right.$ depth) for meiofauna were randomly sampled by SCUBA divers from the dredge track immediately after dredging. The control samples were collected from the study area 


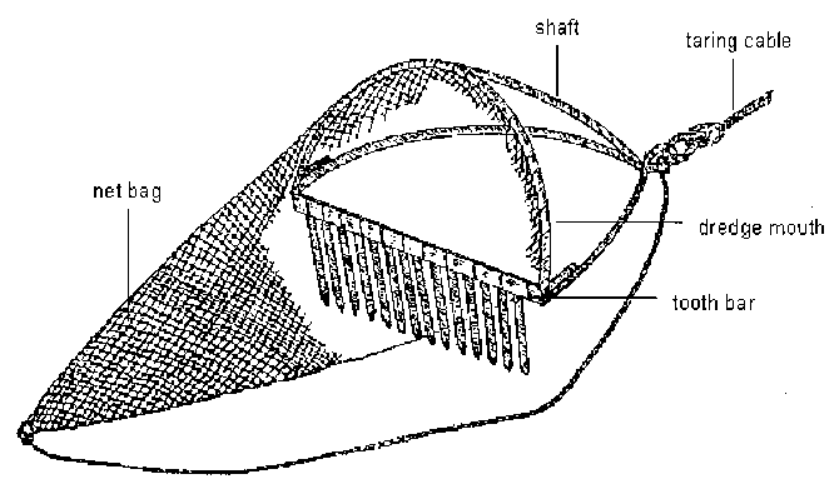

Figure 2. Representative view of a Portuguese clam dredge (according to Monteiro, 1985). Tooth bar, $100 \mathrm{~cm}$; tooth size for Spisula solida, $10 \mathrm{~cm}$; space between tooth, $1.5 \mathrm{~cm}$; net bag, 25-mm mesh size. before dredging, using the same method and number of replicates. This procedure was performed in triplicate on each occasion and location. Macrofauna were sieved in situ using 1-mm mesh bags.

\section{Laboratory procedure}

All the residues were preserved in $70 \%$ ethanol. Meiofauna were sieved using a 500- $\mu \mathrm{m}$ (upper limit) and $150-\mu \mathrm{m}$ (lower limit) mesh sieve. Identification of all organisms in a community to species level is a major time and cost constraint (Warwick, 1993; Clarke \& Warwick, 1994; Somerfield \& Clarke, 1995). Moreover, many studies on meio- and macro-benthic disturbance have shown that very little information is lost by working at a taxonomic level higher than species (e.g. family or even phylum; see Heip et al., 1988; Herman \& Heip, 1988; Warwick, 1988;

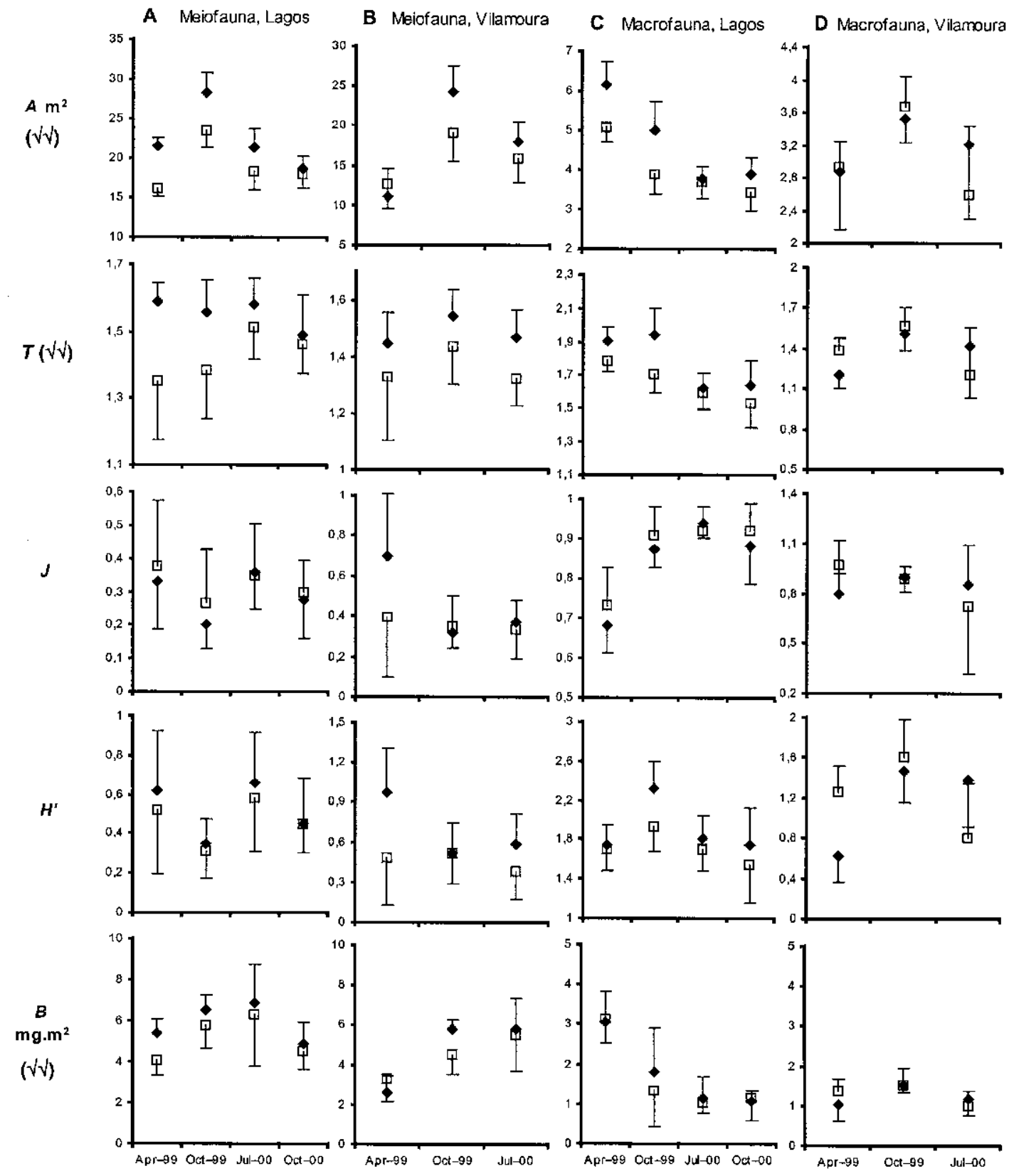

Figure 3. Means and standard deviations of univariate measures: abundance $(A)$, number of taxa $(\mathcal{T})$, Pielou's $\mathcal{F}$, ShannonWiener diversity $\left(H^{\prime}\right)$ and biomass $(B)$ before $(\bullet)$ and after $(\square)$ dredging for: (A) meiofauna from Lagos station; (B) meiofauna from Vilamoura station; (C) macrofauna from Lagos station; (D) macrofauna from Vilamoura station. 
Table 3. Means and standard deviations of the macrofauna abundance $\left(\mathrm{m}^{2}\right)$ before and after dredging, at Lagos and Vilamoura, using data from all seasonal periods. $n$. id., non identified. Blanks represent zeros.

\begin{tabular}{|c|c|c|c|c|c|}
\hline \multirow[b]{2}{*}{ Macrofauna taxa } & & \multicolumn{2}{|c|}{ Lagos } & \multicolumn{2}{|c|}{ Vilamoura } \\
\hline & & Before & After & Before & After \\
\hline Phylum NEMERTINEA & n. id. Nemertinea & $16.0 \pm 31.8$ & $1.3 \pm 4.4$ & & $0.4 \pm 2.4$ \\
\hline Phylum PRIAPULA & n. id. Priapula & $0.2 \pm 1.7$ & & & \\
\hline Phylum SIPUNCULO & n. id. Sipunculo & $10.9 \pm 20.1$ & $2.8 \pm 7.6$ & & \\
\hline Phylum ECHIURA & n. id. Echiura & $0.2 \pm 1.7$ & & & \\
\hline \multirow[t]{25}{*}{ Class POLYCHAETA } & Amphictenidae & $3.8 \pm 10.9$ & $6.4 \pm 14.9$ & & \\
\hline & Aphroditidae & $1.3 \pm 6.6$ & $1.7 \pm 6.7$ & & $0.4 \pm 2.4$ \\
\hline & Arenicolidae & & $0.2 \pm 1.8$ & $1.5 \pm 4.7$ & $0.4 \pm 2.4$ \\
\hline & Capitellidae & $10.0 \pm 19.6$ & $0.9 \pm 3.6$ & & $0.4 \pm 2.4$ \\
\hline & Chaetopteridae & $0.2 \pm 1.7$ & & & \\
\hline & Chlorhaemidae & $0.6 \pm 3.0$ & & & \\
\hline & Cirratulidae & $1.7 \pm 6.5$ & & $3.9 \pm 16.0$ & $4.6 \pm 12.6$ \\
\hline & Eunicidae & $6.6 \pm 14.5$ & $0.6 \pm 3.2$ & & $0.4 \pm 2.4$ \\
\hline & Glyceridae & $1.1 \pm 4.8$ & & $2.4 \pm 5.8$ & $2.8 \pm 9.2$ \\
\hline & Hesionidae & $0.2 \pm 1.7$ & $0.2 \pm 1.8$ & & \\
\hline & Magelonidae & & $0.2 \pm 1.8$ & & \\
\hline & Maldanidae & $2.8 \pm 7.5$ & $3.0 \pm 7.3$ & & \\
\hline & Nephtydidae & $8.5 \pm 14.9$ & $2.6 \pm 5.9$ & $10.2 \pm 14.3$ & $4.3 \pm 8.6$ \\
\hline & Nereidae & $1.9 \pm 6.3$ & $2.1 \pm 6.1$ & $2.9 \pm 8.4$ & $5.0 \pm 11.7$ \\
\hline & Opheliidae & $0.2 \pm 1.7$ & & $0.5 \pm 2.8$ & $0.7 \pm 4.8$ \\
\hline & Orbiniidae & $1.1 \pm 4.8$ & $2.1 \pm 8.9$ & $0.5 \pm 2.8$ & $0.7 \pm 3.3$ \\
\hline & Oweniidae & $0.2 \pm 1.7$ & $0.2 \pm 1.8$ & $0.5 \pm 2.8$ & \\
\hline & Phyllodocidae & $1.7 \pm 7.0$ & $0.6 \pm 3.2$ & & $0.7 \pm 3.3$ \\
\hline & Sabellaridae & $0.2 \pm 1.7$ & & & \\
\hline & Sabellidae & $1.7 \pm 5.5$ & $0.2 \pm 1.8$ & & \\
\hline & Serpulidae & & $0.4 \pm 2.6$ & & \\
\hline & Spionidae & $1.9 \pm 5.7$ & $1.7 \pm 6.7$ & & $1.8 \pm 6.1$ \\
\hline & Syllidae & $0.2 \pm 1.7$ & & & \\
\hline & Terebellidae & $1.1 \pm 5.9$ & $2.8 \pm 8.5$ & & \\
\hline & n. id. Polychaeta & $2.4 \pm 9.7$ & $1.5 \pm 5.4$ & & $0.7 \pm 3.3$ \\
\hline \multirow[t]{31}{*}{ Class BIVALVIA } & Abra alba & $5.6 \pm 32.4$ & & & \\
\hline & A. ovata & $2.6 \pm 13.9$ & & & \\
\hline & Acanthocardia aculeata & $0.2 \pm 1.7$ & & & \\
\hline & A. echinata & $0.2 \pm 1.7$ & & & \\
\hline & A. tuberculata & $1.3 \pm 5.1$ & $2.8 \pm 8.1$ & & \\
\hline & Anomia ephipium & & & & $0.4 \pm 2.4$ \\
\hline & Callista chione & $0.2 \pm 1.7$ & $0.2 \pm 1.8$ & & \\
\hline & Chamelea gallina & $5.3 \pm 14.3$ & $3.6 \pm 10.4$ & $1.0 \pm 3.9$ & $1.8 \pm 6.1$ \\
\hline & Corbula gibba & $0.6 \pm 3.0$ & $0.2 \pm 1.8$ & $1.0 \pm 3.9$ & $0.4 \pm 2.4$ \\
\hline & Digitaria digitaria & & $0.4 \pm 2.6$ & & \\
\hline & Divaricela divaricata & $9.6 \pm 16.2$ & $8.5 \pm 12.4$ & & $0.4 \pm 2.4$ \\
\hline & Donax trunculus & $0.8 \pm 4.2$ & & & \\
\hline & D. variegatus & $6.6 \pm 34.8$ & & $1.0 \pm 3.9$ & $0.7 \pm 3.3$ \\
\hline & D. venustus & $0.9 \pm 3.8$ & $0.6 \pm 3.2$ & & \\
\hline & D. vittatus & $1.7 \pm 11.0$ & & & $0.4 \pm 2.4$ \\
\hline & Dosinea exoleta & $0.8 \pm 5.5$ & $0.9 \pm 3.6$ & $1.5 \pm 4.7$ & \\
\hline & Ensis siliqua & & & & $0.4 \pm 2.4$ \\
\hline & Ervilia nitens & $0.2 \pm 1.7$ & & & \\
\hline & Gari depressa & & & $0.5 \pm 2.8$ & \\
\hline & $G$. fervensis & $0.2 \pm 1.7$ & & & \\
\hline & Loripes lucinalis & $0.4 \pm 2.4$ & $0.2 \pm 1.8$ & & $0.4 \pm 2.4$ \\
\hline & Lutraria anguistor & $1.9 \pm 8.3$ & $2.8 \pm 10.3$ & & \\
\hline & Mactra corallina & $0.4 \pm 2.4$ & & & \\
\hline & M. glauca & $0.2 \pm 1.7$ & & & $0.4 \pm 2.4$ \\
\hline & Modilous adraticus & & & $0.5 \pm 2.8$ & $0.4 \pm 2.4$ \\
\hline & M. barbatus & & & $0.5 \pm 2.8$ & \\
\hline & Myrtea spinifera & $0.4 \pm 3.5$ & $0.2 \pm 1.8$ & & \\
\hline & Mysella bidentata & $58.9 \pm 159.0$ & $48.4 \pm 128.0$ & & \\
\hline & Mysia undata & $0.2 \pm 1.7$ & & & \\
\hline & Pandora inequivalvis & $0.2 \pm 1.7$ & & & \\
\hline & Pharus legumen & $0.4 \pm 2.4$ & $0.4 \pm 2.6$ & & \\
\hline
\end{tabular}


Table 3. Continued.

\begin{tabular}{|c|c|c|c|c|c|}
\hline & Scrobicularia plana & $4.3 \pm 21.0$ & $0.4 \pm 2.6$ & & $0.4 \pm 2.4$ \\
\hline & Spisula elliptica & $1.5 \pm 7.7$ & $1.5 \pm 7.0$ & $0.5 \pm 2.8$ & \\
\hline & S. solida & $2.8 \pm 11.4$ & $0.4 \pm 2.6$ & $27.2 \pm 72.1$ & $8.9 \pm 16.6$ \\
\hline & Spisula subtruncata & $0.6 \pm 3.9$ & $0.6 \pm 3.2$ & & \\
\hline & Tellina incarnata & & $0.4 \pm 2.6$ & $0.5 \pm 2.8$ & $3.9 \pm 12.4$ \\
\hline & T. tenuis & $1.1 \pm 4.8$ & $0.4 \pm 2.6$ & $3.9 \pm 9.8$ & $1.4 \pm 4.6$ \\
\hline & Thracia papyracea & $1.7 \pm 5.5$ & $3.2 \pm 8.7$ & & \\
\hline \multirow[t]{14}{*}{ Class GASTROPODA } & Bela oceanica & $0.4 \pm 3.5$ & & & \\
\hline & B. ornata & $0.2 \pm 1.7$ & & & \\
\hline & Calyptraea chinensis & & & $4.8 \pm 11.7$ & $6.8 \pm 18.5$ \\
\hline & Cylichna cylindracea & $0.4 \pm 2.4$ & & & \\
\hline & Eulima glabra & $0.6 \pm 3.0$ & $1.1 \pm 4.8$ & & \\
\hline & Euspira catena & & & & $0.4 \pm 2.4$ \\
\hline & E. guillemini & $0.2 \pm 1.7$ & $0.2 \pm 1.8$ & & \\
\hline & E. macilenta & & $0.4 \pm 2.6$ & & \\
\hline & Gibbula magus & & & & $0.4 \pm 2.4$ \\
\hline & Gibberula cf. miliaria & $3.2 \pm 9.8$ & $3.4 \pm 9.6$ & & \\
\hline & Leiostraca sebulata & $0.2 \pm 1.7$ & & & \\
\hline & Mesalia brevialis & $0.8 \pm 3.4$ & $0.4 \pm 2.6$ & & \\
\hline & Philine aperta & $0.2 \pm 1.7$ & $0.2 \pm 1.8$ & & \\
\hline & Turritella communis & $10.0 \pm 16.6$ & $6.2 \pm 16.4$ & & \\
\hline Class SCAPHOPODA & Fustiaria rubescens & $0.6 \pm 3.9$ & $0.9 \pm 4.5$ & & \\
\hline Class OSTRACODA & n. id. Ostracoda & $0.4 \pm 2.4$ & $0.2 \pm 1.8$ & & \\
\hline Class COPEPODA & n. id. Copepoda & $0.4 \pm 2.4$ & & & \\
\hline Order CUMACEA & Iphinoe trispinosa & $0.8 \pm 4.2$ & & $1.0 \pm 3.9$ & $0.7 \pm 3.3$ \\
\hline \multirow[t]{2}{*}{ Order TANAIDACEA } & Apseudes latreillii & $7.0 \pm 14.1$ & $0.4 \pm 2.6$ & & \\
\hline & Tanais dulongii & & & & $0.4 \pm 2.4$ \\
\hline \multirow[t]{3}{*}{ Order MYSIDACEA } & Gastrosaccus sanctus & $1.1 \pm 4.1$ & & & \\
\hline & Gastrosaccus sp. & $0.4 \pm 2.4$ & $0.2 \pm 1.8$ & & \\
\hline & Schistomysis spiritus & & & $1.0 \pm 3.9$ & \\
\hline \multirow[t]{3}{*}{ Order ISOPODA } & Cyathura carinata & $0.8 \pm 4.2$ & $0.4 \pm 2.6$ & & \\
\hline & Cirolana cranchii & & $0.4 \pm 2.6$ & $1.0 \pm 3.9$ & $1.1 \pm 4.0$ \\
\hline & Eurydice spinigera & $2.4 \pm 8.0$ & $0.4 \pm 2.6$ & & $1.8 \pm 7.8$ \\
\hline \multirow[t]{10}{*}{ Order AMPHIPODA } & Ampelisca brevicornis & $61.0 \pm 95.1$ & $20.7 \pm 47.4$ & $0.5 \pm 2.8$ & \\
\hline & Atylus vedlomensis & $0.6 \pm 3.0$ & $0.6 \pm 3.2$ & & $0.7 \pm 3.3$ \\
\hline & Dexamine spinosa & $10.7 \pm 26.6$ & $2.6 \pm 6.5$ & $2.4 \pm 7.1$ & $4.3 \pm 14.2$ \\
\hline & Hippomedon denticulatus & $7.7 \pm 15.7$ & $1.3 \pm 5.1$ & $0.5 \pm 2.8$ & $1.1 \pm 4.0$ \\
\hline & Monoculodes carinatus & $0.4 \pm 2.4$ & $0.2 \pm 1.8$ & & $0.7 \pm 3.3$ \\
\hline & Photis cf. longipes & $0.2 \pm 1.7$ & $1.1 \pm 5.5$ & & $0.4 \pm 2.4$ \\
\hline & Phtisica marina & & $1.7 \pm 14.8$ & & \\
\hline & Pontocrates arenarius & $0.9 \pm 5.7$ & $0.2 \pm 1.8$ & $1.0 \pm 5.6$ & \\
\hline & Siphonoecetes striatus & $20.5 \pm 28.9$ & $17.3 \pm 31.5$ & $1.5 \pm 6.1$ & $0.7 \pm 3.3$ \\
\hline & Urothoe poseidonis & $37.8 \pm 41.4$ & $18.8 \pm 29.6$ & $8.7 \pm 23.4$ & $3.6 \pm 15.0$ \\
\hline \multirow{12}{*}{ Order DEGAPODA } & Atelecyclus undecimdentatus & & $0.2 \pm 1.8$ & & \\
\hline & Philocheras trispinosus & $0.4 \pm 2.4$ & $0.2 \pm 1.8$ & & \\
\hline & Diogenes pugilator & $32.4 \pm 47.3$ & $17.5 \pm 25.9$ & $0.5 \pm 2.8$ & $0.7 \pm 4.8$ \\
\hline & Hippolyte varians & & $0.2 \pm 1.8$ & & \\
\hline & Liocarcinus holsatus & $0.8 \pm 6.9$ & & & \\
\hline & L. marmoreus & & $0.6 \pm 5.5$ & & \\
\hline & L. pusillus & $0.2 \pm 1.7$ & $0.9 \pm 3.6$ & $0.5 \pm 2.8$ & \\
\hline & L. vernalis & $0.2 \pm 1.7$ & & & \\
\hline & Parthenope massena & & & & $0.4 \pm 2.4$ \\
\hline & Pirimela denticulata & $0.2 \pm 1.7$ & & & $0.4 \pm 2.4$ \\
\hline & Processa parva & $2.8 \pm 7.5$ & $1.7 \pm 8.1$ & $2.9 \pm 7.4$ & $1.8 \pm 5.1$ \\
\hline & Thia scutellata & $0.4 \pm 2.4$ & $0.4 \pm 2.6$ & & \\
\hline Class ASTEROIDEA & Astropecten irregularis & & $0.2 \pm 1.8$ & & $0.4 \pm 2.4$ \\
\hline \multirow[t]{3}{*}{ Class OPHIUROIDEA } & Amphipholis squamata & $0.2 \pm 1.7$ & & & \\
\hline & Amphiura mediterranea & $94.5 \pm 194.7$ & $21.8 \pm 42.3$ & $24.7 \pm 34.0$ & $14.6 \pm 23.3$ \\
\hline & Ophiura texturata & $3.4 \pm 12.4$ & $0.9 \pm 4.5$ & $10.7 \pm 18.6$ & $26.7 \pm 40.5$ \\
\hline \multirow[t]{3}{*}{ Class ECHINOIDEA } & Echinocardium cordatum & $6.0 \pm 9.9$ & $4.3 \pm 9.2$ & $3.9 \pm 8.0$ & $5.3 \pm 7.6$ \\
\hline & Echinocianus pusilus & $0.2 \pm 1.7$ & & & \\
\hline & Psamoechinus miliaris & & & & $0.4 \pm 2.4$ \\
\hline Phylum HEMICHORDATA & Branchiostoma lanceolatum & $13.2 \pm 41.5$ & $1.7 \pm 6.7$ & $1.5 \pm 4.7$ & $1.1 \pm 4.0$ \\
\hline InfraClass TELEOSTEI & Teleostei & & $0.2 \pm 1.8$ & & \\
\hline Others & n. id. Taxa & $1.5 \pm 7.2$ & $1.7 \pm 6.2$ & & \\
\hline
\end{tabular}



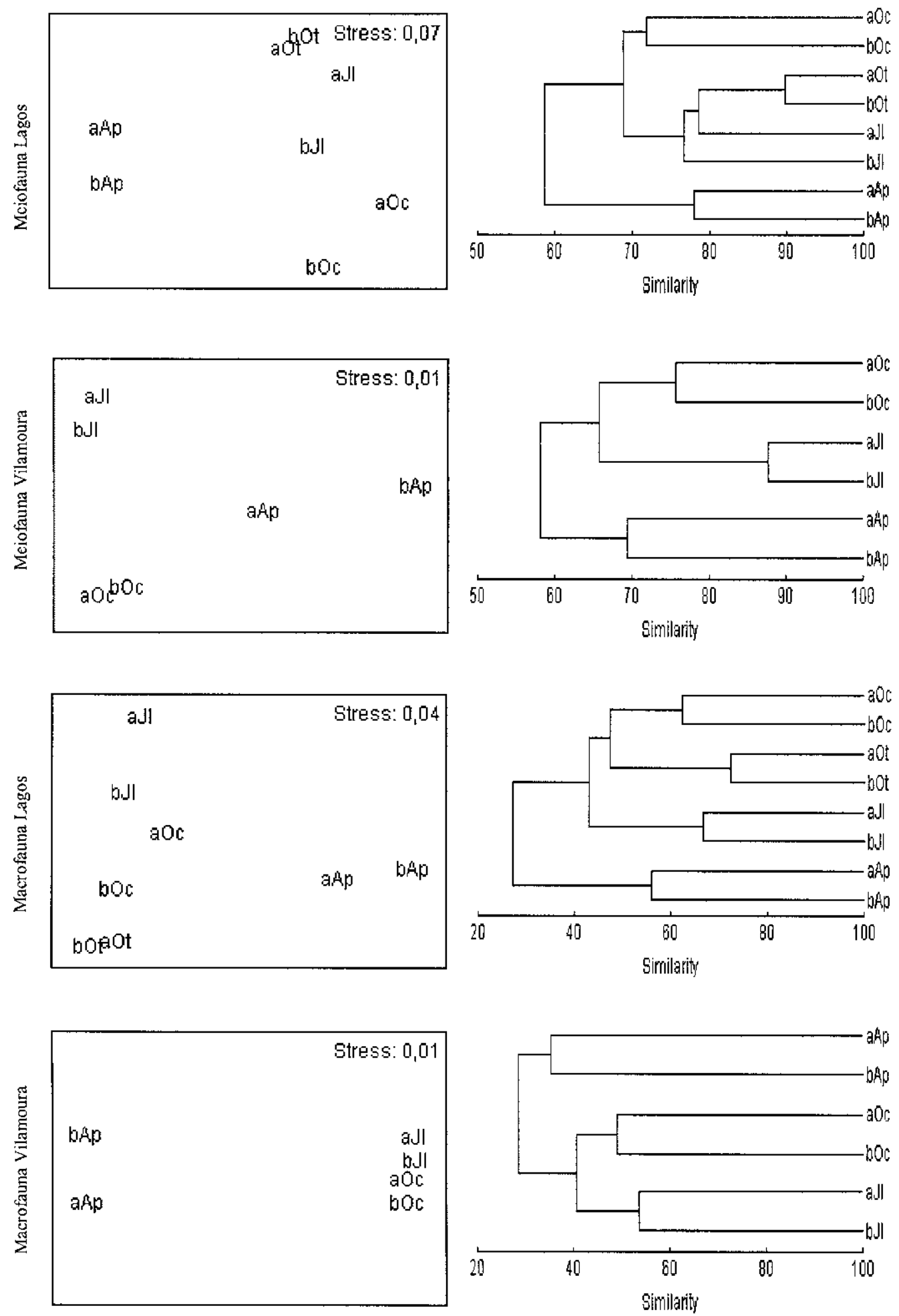

Figure 4. Multidimensional scaling (left) and cluster (right) ordinations for meiofauna and macrofauna abundances from Lagos and Vilamoura, before (b) and after (a) dredging on different seasons (Ap, April 1999; Oc, October 1999; Jl, July 2000; Ot, October 2000).

Warwick et al., 1990). Thus, we decided to sort meiofauna by phylum or order, and to sort macrofauna to the lowest possible taxonomic level with the exception of a few groups.

Ash-free dry weight was calculated for macrofauna biomass determinations. These animals were dried at $60^{\circ} \mathrm{C}$ until constant weight (at least $48 \mathrm{~h}$ ) and then burned at $450^{\circ} \mathrm{C}$ for three hours in a muffle-furnace. Meiofaunal biomass was calculated following Banse (1982), Knox (1986) and Sprung (1994).

\section{Data analysis}

Univariate measures of community structure. Univariate measures included: total abundance $(A)$, number of taxa $(T)$, evenness (Pielou's $\mathcal{f}$ ), Shannon-Wiener diversity indices, which were calculated using base- $e$ logarithms $\left(H^{\prime}\right)$, and biomass $(B) . A$ and $B$ were converted to square metres. $A, T$ and $B$ were then converted to approximate normality using a double square root transformation $(\sqrt{ } \sqrt{ })$, and the 
Table 4. $R$ and significance levels (P) from two-way crossed ANOSIM tests for meiofauna and macrofauna community structure between (1) before/after dredging and (2) seasons, at Lagos and Vilamoura.

\begin{tabular}{llllr}
\hline Taxa & Area & Effect & R & P-level \\
\hline \multirow{2}{*}{ Meiofauna } & Lagos & 1 & 0.138 & $<0.01$ \\
& & 2 & 0.651 & $<0.01$ \\
& Vilamoura & 1 & 0.103 & 0.06 \\
& & 2 & 0.483 & $<0.01$ \\
Macrofauna & Lagos & 1 & 0.249 & $<0.01$ \\
& & 2 & 0.715 & $<0.01$ \\
& Vilamoura & 1 & 0.218 & $<0.01$ \\
& & 2 & 0.521 & $<0.01$ \\
\hline
\end{tabular}

significance of differences between before/after dredging and seasons were tested using two-way ANOVA ( $F$-test). This analysis was accomplished for meiofauna and macrofauna in both areas, totalling 20 two-way ANOVA tests. The ANOVA assumptions, namely the normal distribution and the homogeneity of variances, were tested using Chisquare and Levene's tests, respectively. All tests were performed using the STATISTICA 5 program. The mean and standard deviation of species abundance between before and after dredging were also determined for meiofauna and macrofauna in both areas.

Multivariate analyses of community structure. Non-parametric multivariate techniques were used, as discussed by Clarke (1993). Lower triangular similarity matrices were constructed using a range of data transformations and the

Table 5. Results of the SIMPER analysis applied between before and after dredging on fourth-root transformed meiofauna and macrofauna, at Lagos and Vilamoura, using data from all seasonal periods. The table shows the contribution (contrib.) and cumulative (cum.) per cent of the species that most contribute to the Bray-Curtis dissimilarities. The cut off was $75 \%$ for meiofauna and $60 \%$ for macrofauna.

Meiofauna

\begin{tabular}{|c|c|c|c|c|c|}
\hline \multicolumn{3}{|c|}{$\begin{array}{l}\text { Lagos } \\
\text { average dissimilarity }=37.58\end{array}$} & \multicolumn{3}{|c|}{$\begin{array}{c}\text { Vilamoura } \\
\text { average dissimilarity }=45.99\end{array}$} \\
\hline Taxa & Contrib. \% & Cum. \% & Taxa & Contrib. \% & Cum. $\%$ \\
\hline Class OLIGOCHAETA & 13.57 & 13.57 & Order COPEPODA & 17.32 & 17.32 \\
\hline Phylum NEMATODA & 13.30 & 26.88 & Phylum NEMATODA & 15.25 & 35.58 \\
\hline Order COPEPODA & 11.89 & 38.77 & Class POLYCHAETA & 10.34 & 42.91 \\
\hline Class POLYCHAETA & 8.76 & 47.53 & Phylum NEMERTINEA & 8.84 & 51.76 \\
\hline Class BIVALVIA & 7.96 & 55.50 & Class HALACAROIDEA & 8.68 & 60.44 \\
\hline Phylum NEMERTINEA & 7.31 & 62.81 & Class BIVALVIA & 7.63 & 68.06 \\
\hline Order OSTRACODA & 6.91 & 69.72 & Class TURBELLERIA & 7.11 & 75.17 \\
\hline Order TANAIDACEA & 6.88 & 76.61 & & & \\
\hline
\end{tabular}

Macrofauna

\begin{tabular}{|c|c|c|c|c|c|}
\hline \multicolumn{3}{|c|}{$\begin{array}{c}\text { Lagos } \\
\text { average dissimilarity }=77.00\end{array}$} & \multicolumn{3}{|c|}{$\begin{array}{c}\text { Vilamoura } \\
\text { average dissimilarity }=80.59\end{array}$} \\
\hline Taxa & Contrib. $\%$ & Cum. \% & Taxa & Contrib. $\%$ & Cum. \% \\
\hline Ampelisca brevicornis & 5.22 & 5.22 & Amphiura mediterranea & 9.42 & 9.42 \\
\hline Urothoe poseidonis & 5.09 & 10.31 & Ophiura texturata & 9.22 & 18.64 \\
\hline Amphiura mediterranea & 4.93 & 15.24 & Spisula solida & 9.19 & 27.83 \\
\hline Diogenes pugilator & 4.80 & 20.04 & Nephtydidae & 6.88 & 34.71 \\
\hline Siphonoecetes striatus & 4.69 & 24.73 & Echinocardium cordatum & 5.08 & 39.79 \\
\hline Mysella bidentata & 4.24 & 28.97 & Calyptraea chinensis & 4.47 & 44.26 \\
\hline Divaricela divaricata & 3.70 & 32.67 & Glyceridae & 3.60 & 47.86 \\
\hline Turritella communis & 3.35 & 36.02 & Nereidae & 3.58 & 51.44 \\
\hline Echinocardium cordatum & 2.90 & 38.92 & Tellina tenuis & 3.25 & 54.69 \\
\hline Sipunculo n. id. & 2.79 & 41.71 & Processa parva & 3.01 & 57.71 \\
\hline Nephtydidae & 2.63 & 44.34 & Dexamine spinosa & 2.88 & 60.59 \\
\hline Nemertinea n. id. & 2.22 & 46.56 & & & \\
\hline Branchiostoma lanceolatum & 2.11 & 48.68 & & & \\
\hline Amphictenidae & 2.08 & 50.76 & & & \\
\hline Dexamine spinosa & 2.01 & 52.77 & & & \\
\hline Chamelea gallina & 1.96 & 54.73 & & & \\
\hline Hippomedon denticulatus & 1.89 & 56.62 & & & \\
\hline Capitellidae & 1.82 & 58.44 & & & \\
\hline Photis cf. longipes & 1.74 & 60.18 & & & \\
\hline
\end{tabular}


Bray-Curtis similarity measure. Transformations were used to reduce contributions to similarity by abundant species, and therefore to increase the importance of the less abundant species in the analyses. Nematodes and macrofauna vary in abundance between single individuals and thousands of specimens between samples, so a fourth-root transformation was applied. Ordination was by cluster and non-metric multidimensional scaling (MDS; see Kruskal \& Wish, 1978; Clarke \& Green, 1988). Ordination was analysed with averaged samples to amenable interpretation reducing the high number of replicates in the plot. Formal significance tests for differences between before and after dredging and seasons were performed using the ANOSIM two-way crossed permutation test (Clarke \& Green, 1988; Clarke, 1993). The species contributing to dissimilarities between pre- and post-dredging analysis - using data from all seasonal periods-were investigated using the similarities percentages procedure (SIMPER; see Clarke, 1993). Multivariate analyses were performed using the PRIMER 5 program.

\section{RESULTS}

\section{Univariate measures of community structure}

Variations in meiofauna evenness $(\mathcal{J})$ and diversity $\left(H^{\prime}\right)$ at Lagos were not significant between pre- and postdredging communities, but the variations in other measures such as abundance $(A)$, number of taxa $(\mathcal{T})$ and biomass $(B)$ were highly significant. Variations between seasons were significant for all measures (Figure 3A, Table 1), lower values being found during October 2000. Interactions between pre- and post-dredging and seasons showed significant variations in $A$ and $\mathcal{T}$. Univariate measures derived from meiofauna at Vilamoura showed that only $T$ and $H^{\prime}$ varied significantly between pre- and post-dredging communities, and that all, except for $T$, varied significantly between seasons (Figure 3B, Table 1). However, the interactions between pre- and post-dredging and seasons revealed no significant variations.

All univariate measures derived from macrofauna data at Lagos varied significantly between pre- and post-dredging communities (with the exception of $B$ ) and between seasons (Figure $3 \mathrm{C}$, Table 1). The interactions between preand post-dredging and seasons revealed significant variations in $A$ and $T$. In relation to macrofauna at Vilamoura, no univariate measures varied significantly between preand post-dredging communities. By contrast, all measures, except for $\mathcal{H}$, varied significantly between seasons (Figure 3D, Table 1), with higher values in October 1999. The interactions between pre- and post-dredging and seasons revealed significant variations only in $T$ and $H^{\prime}$.

Concerning average taxa abundance, the Phylum Nematoda was clearly the most abundant taxon present in meiofauna $(\approx 80 \%)$, at both Lagos and Vilamoura, generally followed by the Copepoda, Polychaeta, Turbellaria and Oligochaeta. With the exception of Copepoda and Halacaroidea, all the remaining taxa were more abundant at Lagos than at Vilamoura, as were the overall number of taxa. In both areas, all taxa decreased in abundance except for the Nemertinea and Tanaidacea at Lagos and the Bivalvia and Cumacea at Vilamoura, which showed the opposite trend. From before to after dredging, Nematoda decreased from a mean of 293730 ( \pm 263584$)$ to 127677 ( \pm 99623 ) individuals per square metre in Lagos and from $122450( \pm 125925)$ to $84000( \pm 86434)$ in Vilamoura. Only the taxa Cladocera at Lagos and Cnidaria, Gastropoda and Sipunculo at Vilamoura were registered after dredge disturbance (Table 2).

Our use of the higher level of taxonomic specification of the macrofauna allowed identification of 125 taxa, divided into 91 species, one genus, 24 families (polychaetes), one infraclass and eight unidentified taxa, during samplings at Lagos and Vilamoura. Again, Lagos showed a higher number of taxa (114) than Vilamoura (61). There was no evidence of a clear pattern of decrease in the mean abundance for all taxa in general, as observed for meiofauna, after dredge disturbance. Thus for both areas, there was a decrease in the mean abundance of specific taxa such as Nephtydidae (polychaetes), Corbula gibba, Spisula solida, Tellina tenuis (bivalves), amphipods in general, Processa parva (shrimp) and Amphiura mediterranea (brittle-star), and an increase in others such as Nereidae and Orbinidae (polychaetes). Species such as Ophiura texturata (brittle-star), Echinocardium cordatum (sea-urchin) and Dexamine spinosa and Hippomedon denticulatus (amphipods) showed marked decreases in mean abundance in Lagos and increases in Vilamoura after dredge disturbance (Table 3).

Meio- and macro-benthic communities in Lagos and Vilamoura registered higher values of abundance and biomass in the October sampling seasons, although such a seasonal pattern was not always clear.

\section{Multivariate analyses of community structure}

Cluster and MDS ordination of fourth-root transformed averaged data clearly showed that the pre-dredging communities clustered separately from the post-dredging ones, however the major community changes were found between seasons (Figure 4). The ANOSIM two-way crossed significance tests indicate that all are significantly different $(P<0.01)$, except for meiofauna at Vilamoura, confirming clear major changes between seasons (higher R values, Table 4). Similarities percentage analyses (SIMPER) of fourth-root transformed meiofauna and macrofauna abundances were used to determine the contributions from individual taxa to the Bray-Curtis dissimilarities between pre- and post-dredging treatment. Variations in the abundance of nematodes, copepods, polychaetes and to a lesser extent bivalves, common to Lagos and Vilamoura, accounted for most of the meiofauna dissimilarities between pre- and post-dredging communities. The average dissimilarity between pre- and post-dredging treatment was 37.58 for Lagos and 45.99 for Vilamoura (Table 5). Concerning macrofauna, higher mean dissimilarity was observed between pre- and post-dredging communities, with 77.00 for Lagos and 80.59 for Vilamoura. The taxa that most contributed to these dissimilarities differed between areas. Variations in abundance of Ampelisca brevicornis, Urothoe poseidonis and Siphonoecetes striatus (amphipods), Amphiura mediterranea (brittle-star) and Diogenes pugilator (hermit crab) in Lagos, and of Amphiura mediterranea and Ophiura texturata (brittle-stars), Spisula solida (bivalve) and Nephtydidae, Glyceridae and Nereidae (polychaetes) in Vilamoura, accounted for most of the macrofauna dissimilarity between pre- and post-dredging communities (Table 5). 


\section{DISCUSSION}

Dredging activity was found to cause changes in abundance $(A)$, number of taxa $(\mathcal{T})$, evenness $(\mathcal{f})$, diversity $\left(H^{\prime}\right)$ and biomass $(B)$ in the meio- and macro-benthic community structure. Changes were also found between seasons. As a general pattern, all measures showed a decrease after dredge disturbance for meiofauna and macrofauna in both areas, except for the macrofauna at Vilamoura during April and October 1999, which showed the opposite trend. Curiously, the natural changes between seasons were significantly higher than those changes resulting from shortterm dredging disturbance.

These changes among the post-dredge communities are consistent with Clarke \& Warwick's (1994) statement that meio- and macro-benthic communities are sensitive to anthropogenic disturbances in the marine environment. Further, they also support the conclusions of Kaiser \& Spencer (1996) and Currie \& Parry (1999), that fishing impact is a major factor influencing changes in the biodiversity and taxonomic composition of a community structure. Indeed, several other experimental studies of habitat disturbance by fishing have also demonstrated general decreases in community parameters. For example, Bergman \& Hup (1992) showed 10-65\% reductions in echinoderm, polychaete and mollusc densities after trawling. Eleftheriou \& Robertson (1992) noted negative effects on heart urchin (Echinocardium sp.) densities. Trush et al. (1995) observed a decrease in species richness and diversity due to scallop dredging, and Currie \& Parry (1996) reported a $20-30 \%$ decrease in infaunal abundance following commercial scallop dredging. A general decrease in biodiversity after dredge disturbance (short-term impact) has also been observed for oyster shell dredging (Conner \& Simon, 1979), beam trawling (Kaiser \& Spencer, 1996) and rapido trawling (Pranovi et al., 2000) in other regions.

In the present study, despite the general decrease in the biodiversity of both meio- and macro-benthic communities after the passage of the dredging gear, the macrofauna tended to be more affected than meiofauna, even when considering the higher discrepancies in the abundance of the latter. This is supported by several data including macrofauna length, which implies that organisms larger than the mesh size were captured. Thus, while in the Portuguese dredge fishery by-catch species with no commercial value are discarded immediately after sorting, and several studies have showed that discarded organisms may have high survival rates (Kaiser \& Spencer, 1995; Gaspar et al., 2001), some organisms clearly suffered direct mortality. This probably resulted from the impact of the gear, pressure inside the net bag or even from the surface anoxia or temperature. Moreover, the average dissimilarity values (from SIMPER) obtained for macrofauna were higher than those obtained for meiofauna. The significance levels (from ANOSIM) were significantly different for macrofauna at both Lagos and Vilamoura, but only for meiofauna at Lagos; moreover the $\mathrm{R}$ values (from ANOSIM) were higher for macrofauna than for meiofauna. Thus we suggest that the short-term effects of dredging upon the meiofauna is mainly due to sediment redistribution rather than to actual changes to the benthic communities, as organisms may be too small to suffer any damage and/or be caught during the fishing process.
Nematoda, Copepoda and Polychaeta generally dominated the meiofauna in the pre- and post-dredging communities at Lagos and Vilamoura. Because of their high abundances, especially the dominance of the Phylum Nematoda, which represented $\approx 80 \%$ of total meiofauna, the Shannon-Wiener diversity for meiofauna was lower than for macrofauna. This high abundance of Nematoda has also been reported in other regions (e.g. Heip et al., 1988; Warwick et al., 1990).

For macrofauna at Vilamoura, instead of the expected reduction in the univariate measures after the dredge impact, the opposite trend was observed in April and October 1999. This is probably because Vilamoura has been a continuously disturbed area, while dredging activity had been stopped in Lagos as a response to over-fishing. Both locations are within a bivalve fishing area and had been under severe dredge-fishing impact until four years before this study. This could explain the opposite changes observed in the macrofauna for the two areas, as noted by Chícharo et al. (2002b). The increase in the univariate measures at Vilamoura after the passage of the gear might indicate more aggressive behaviour of the predator species in this long-term fished area, where predators have learned to relate the dredging activity to the availability of prey, as observed by Chícharo et al. (2003). At Liverpool Bay, Kaiser et al. (1998) mentioned a similar behaviour under similar circumstances, where the abundance of some species decreased (target and more fragile species) and others apparently increased (predators). In fact, the SIMPER results show that the taxa that most contributed to the dissimilarity between pre- and post-dredge disturbance in Vilamoura were represented by target (e.g. bivalve Spisula solida) and more fragile taxa (e.g. brittle-star Amphiura mediterranea, seaurchin Echinocardium cordatum, polychaete Glyceridae and bivalve Tellina tenuis), and by potential predators (brittlestar Ophiura texturata, polychaetes Nephtydidae, Nereidae and shrimp Processa parva). In this case, we considered potential predators to be those scavengers, carnivores or omnivores with the capability of aggregating on the track after the passage of the dredge. Our analysis of the preand post-dredging abundance of macrofauna confirmed a general pattern of taxa abundance after the passage of the dredge. First, the target and more fragile taxa decreased in mean abundance, suggesting that they were caught by the gear. Second, the potential predators increased in mean abundance, suggesting that they aggregated on the track after the passage of the dredge. The exceptions were the polychaetes Nephtydidae that, despite being described as scavenging and carnivorous (Commito, 1982; Bemvenuti, 1994), appeared to be caught or damaged by the dredge. The other exception was the sea-urchin E. chordatum. While we expected a reduction in its mean abundance after the passage of the dredge as noted by Eleftheriou \& Robertson (1992), an increase was observed.

On the other hand, at Lagos we observed that the first 13 taxa that most contributed to the dissimilarities decreased in abundance following disturbance. The majority of these taxa were found to be essentially feeders or the herbivorous: amphipods Ampelisca brevicornis, Urothoe poseidonis and Siphonoecetes striatus, the brittle-star Amphiura mediterranea, the sea-urchin Echinocardium cordatum, bivalves and the gastropod Turritella communis. From these taxa that 
most contributed to this dissimilarity, we consider that the potential predators could only be the hermit crab Diogenes pugilator and the polychaete Nephtydidae. However, we observed that the mean abundances of these fauna also decreased after disturbance. The differences observed in the community structure as well as in the predators and preys between Lagos and Vilamoura could suggest longterm effects of dredge disturbance, although such potential effects are outside the scope of this paper.

From the analysis of the macrofauna taxa from Lagos, it appears that the amphipods Ampelisca brevicornis, Urothoe poseidonis and Siphonoecetes striatus and the bivalves Mysella bidentata and Divaricela divaricata were never retained on the net bag due to their large size. These species are probably spread across the sea-floor, and therefore it is probable that their abundances might increase in the areas adjacent to the dredge track. Thus, the short-term effects of dredging for meiofauna are mainly due to sediment redistribution rather than actual changes to the benthic communities, as organisms may be too small to suffer any damage and/or be caught during the fishing process. This may also apply to the smaller macrofauna.

High and significant natural changes were observed between seasons in the meio- and macro-benthic community structures. Higher abundance and biomass were registered in the October sampling seasons, although such seasonal patterns were not always clear. Naturally occurring and interrelated factors are known to influence the community structure of the benthos, such as temperature (Beukema, 1992), storms and wave or current action. There are also seasonal variations in species abundance and diversity due to the differing life cycles of different species and variable year-to-year recruitment (Bradshaw et al., 2000). In fact, the biological and physical factors, such as the few storms that were observed during the winters, the low depths of these benthic communities (subject to water turbulence) and the temperature discrepancies between seasons in the Algarve coast, could justify the seasonal variations registered for the benthic community structure.

Thus this study supports the view that Portuguese clam dredging is responsible for short-term changes in meiofauna and macrofauna community structure, including effects on non-target species and habitat destruction. However, greater significant natural changes were found between seasons, indicating that this fishing gear causes only small-scale impacts. Further studies aiming to detect short-term changes in these ecosystems should consider a comparison between these changes and the natural seasonal fluctuations to provide a degree of comparison, and to therefore better assess short-term changes.

This study was carried out with financial support from the Commission of the European Communities, Agriculture and Fisheries (FAIR) specific RTD programme PL-4465, ECODREDGE. Thanks are also due to the EcoResources Group for help with sampling procedure, and to IPIMAR/ CRIPsul for logistical support. Our thanks also due to Dr Richard Warwick (Plymouth Marine Laboratory) for his suggestions on the data analysis, that have significantly improved the paper.

\section{REFERENCES}

Banse, K., 1982. Mass-scale rates of respiration and intrinsic growth in very small invertebrates. Marine Ecology Progress Series, 9, 281-297.

Bemvenuti, C.E., 1994. O poliqueta Nephtys fluviatilis Monro, 1937, como predador da infauna na comunidade de fundos moles. Atlântica Rio Grande, 16, 87-98.

Bergman, M. \& Hup, M., 1992. Direct effects of beamtrawling on macrofauna in a sandy sediment in the southern North Sea. ICES Fournal of Marine Science, 49, 5-11.

Beukema, J.J., 1992. Long-term and recent changes in the benthic macrofauna living on tidal flats in the western part of the Wadden Sea. Netherlands Institute for Sea Research, 20, 135-141.

Bottrell, H.H. \& Robins, D.B., 1984. Seasonal variations in length, dry weight, carbon and nitrogen of Calanus helgolandicus from the Celtic Sea. Marine Ecology Progress Series, 14, 259-268.

Bradshaw, G., Veale, L.O., Hill, A.S. \& Brand, A.R., 2000. The effects of scallop dredging on gravely seabed communities. In The effects of fishing on non-target species and habitats: biological, conservation and socio-economic issues (ed. M.J. Kaiser and S.J. Groot), pp. 83-104. Oxford: Blackwell Science.

Buhl-Jensen, L. \& Fosså, J.H., 1991. Hyperbenthic crustacean fauna of the Gullmarfjord area (western Sweden): species richness, seasonal variation and long-term changes. Marine Biology, 109, 245-258.

Caddy, J.F., 1968. Underwater observations on scallop (Plactopecten magellanicus L.) behaviour and drag efficiency. Fournal of the Fisheries Research Board of Canada, 25, 2123-2124.

Caddy, J.F., 1973. Underwater observations on tracks of dredges and trawls and some effects of dredging on a scallop ground. Fournal of the Fisheries Research Board of Canada, 30, 173-180.

Chícharo, L., Regala, J., Gaspar, M., Alves, F. \& Chícharo, A., 2002a. Macrofauna spatial differences within clam dredgetracks and their implications for short-term fishing effect studies. Fisheries Research, 54, 349-353.

Chícharo, L., Chícharo, A., Gaspar, M., Alves, F. \& Regala, J., 2002b. Ecological characterization of dredged and nondredged bivalve fishing areas off south Portugal. Fournal of the Marine Biological Association of the United Kingdom, 82, 41-50.

Chícharo, L., Chícharo, M., Gaspar, M., Regala, J. \& Alves, F., 2003. Reburial time and indirect mortality of Spisula solida clams caused by dredging. Fisheries Research, 59, 247-258.

Clarke, K.R., 1993. Non-parametric multivariate analyses of changes in community structure. Australian Fournal of Ecology, 18, 117-143.

Clarke, K.R. \& Green, R.H., 1988. Statistical design and analysis for a 'biological effects' study. Marine Ecology Progress Series, 46, 213-226.

Clarke, K.R. \& Warwick, R.M., 1994. Changes in marine communities: an approach to statistical analysis and interpretation. Swindon: Natural Environment Research Council.

Commito, J.A., 1982. Importance of predation by infaunal polychaetes in controlling the structure of a soft-bottom community in Maine, USA. Marine Biology, 68, 77-81.

Conner, W.G. \& Simon, J.L., 1979. The effects of oyster shell dredging on an estuarine benthic community. Estuarine and Coastal Marine Science, 9, 749-758.

Cunha, M.R., Sorbe, J.C. \& Moreira, M.H., 1999. Spatial and seasonal changes of brackish peracaridan assemblages and their relation to some environmental variables in two tidal channels of the Ria de Aveiro (NW Portugal). Marine Ecology Progress Series, 190, 69-87.

Currie, D.R. \& Parry, G.D., 1996. Effects of scallop dredging on a sort sediment community: a large scale experimental study. Marine Ecology Progress Series, 134, 131-150.

Currie, D.R. \& Parry, G.D., 1999. Impacts and efficiency of scallop dredging on different soft substrates. Canadian Fournal of Fisheries and Aquatic Sciences, 56, 539-550. 
Eleftheriou, A. \& Robertson, M.R., 1992. The effects of experimental scallop dredging on the fauna and physical environment of a shallow sandy community. Netherlands Fournal of Sea Research, 30, 289-299.

Gaspar, M.B., 1996. Bivalves do litoral oceânico algarvio. Aspectos da biologia, ecologia e da pescaria dos mananciais de interesse económico: aplicação à gestão dos recursos. Tese de Doutoramento, Universidade do Algarve, Faro, Portugal.

Gaspar, M.B., Castro, M. \& Monteiro, C.C., 1998. Influence of tow duration and tooth length on the number of damaged razor clams Ensis siliqua. Marine Ecology Progress Series, 169, 303-305.

Gaspar, M.B., Dias, M.D., Campos, A., Monteiro, C.C., Santos, M.N., Chícharo, A. \& Chícharo, L., 2001. The influence of dredge design on the catch of Callista chione (Linnaeus, 1758). Hydrobiologia, 465, 153-167.

Gaspar, M.B., Richardson, C.A. \& Monteiro, C.C., 1994. The effects of dredging on shell formation in the razor clam Ensis siliqua from Barrinha, southern Portugal. Fournal of the Marine Biological Association of the United Kingdom, 74, 927-938.

Groot, S. de, 1984. The impact of bottom trawling on benthic fauna of the North Sea. Ocean Management, 9, 177-190.

Hall, S.J., Basford, D.J. \& Robertson, M.R., 1990. The impact of hydraulic dredging for razor clams Ensis sp. on an infaunal community. Netherlands Fournal of Sea Research, 27, 119-125.

Hamerlynck, O. \& Mees, J., 1991. Temporal and spatial structure in the hyperbenthic community of a shallow coastal area and its relation to environmental variables. Actes de Colloque International-sur-l'environment des Mers Epicontinentales, Lille (ed. by H. Chamley), 11, 205-212.

Heip, H., Warwick, R.M. \& Carr, M.R., 1988. Analysis of community attributes of the benthic meiofauna of Frierfjord/ Langesundfjord. Marine Ecology Progress Series, 46, 171-180.

Herman, P.M.J. \& Heip, C., 1988. On the use of meiofauna in ecological monitoring: who needs taxonomy? Marine Pollution Bulletin, 19, 665-668.

Holme, N.A., 1983. Fluctuations in the benthos of the western English Channel. Oceanological Acta, Proceedings 17th EMBS, Brest, France, $\bullet \bullet, 121-124$.

Jennings, S., Pinnegar, J.K., Polunin, N.V.C. \& Warr, K.S., 2001. Impacts of trawling disturbance on the trophic structure of benthic invertebrate communities. Marine Ecology Progress Series, 213, 127-142.

Kaiser, M.J., Edwards, D.B., Armstrong, P.A., Radford, K., Lough, N.E.L., Flatt, R.P. \& Jones, H.D., 1998. Changes in megafaunal benthic communities in different habitats after trawling disturbance. ICES fournal of Marine Science, 55, 353-361.

Kaiser, M.J. \& Spencer, B.E., 1994. Fish scavenging behaviour in recently trawled areas. Marine Ecology Progress Series, 112, 41-49.

Kaiser, M.J. \& Spencer, B.E., 1995. Survival of by-catch from a beam trawl. Marine Ecology Progress Series, 126, 31-38.

Kaiser, M.J. \& Spencer, B.E., 1996. The effects of beam-trawl disturbance on infaunal communities in different habitats. Fournal of Animal Ecology, 65, 1-25.

Knox, G.A., 1986. Estuarine ecosystems: a systems approach, vol. II. Florida: CRC Press Inc.

Kruskal, J.B. \& Wish, M., 1978. Multidimensional scaling. Beverly Hills: Sage Publications.
Meyer, T.L., Cooper, R. \& Pecci, K.J., 1981. The performance and environmental effects of a hydraulic clam dredge. Marine Fisheries Review, 43, 1-9.

Monteiro, C.L.C., 1985. Prospecção preliminar dos bivalves de interesse comercial do litoral algarvio. Área de Sotavento. Relatório. Instituto Nacional de Investigação das Pescas, Lisboa, no. 44, 110 pp.

Ólafsson, E. \& Elmgren, R., 1997. Seasonal dynamics of sublittoral meiobenthos in relation to phytoplankton sedimentation in the Baltic Sea. Estuarine and Coastal Shelf Sciences, 45, 149-164.

Pranovi, F. \& Giovanardi, O., 2000. La pesca di molluschi bivalvi nella Laguna di Venezia: effetti e conseguenze. Biologia Marina Mediterranea, 2, 121-122.

Pranovi, F., Raicevich, S., Franceschini, G., Farrace, M.G. \& Giovanardi, O., 2000. Rapido trawling in the northern Adriatic Sea: effects on benthic communities in an experimental area. ICES Journal of Marine Science, 57, 517-524.

Robinson, S.M.C. \& Rowell, TW. 1990. The effects of the tradi- col 2 tional clam hack on mortality rates of pre-recruited soft shell ${ }_{\text {Symp. in }}^{1990}$ clams during different seasons of the year. ICES Shell Symp, 130. full? also Somerfield, P.J. \& Glarke, K.R., 1995. Taxonomic levels in page nos? marine community studies, revisited. Marine Ecology Progress Series, 127, 113-119.

Sorbe, J.C., 1999. Deep-sea macrofaunal assemblages within the Benthic Boundary Layer of the Cap-Ferret Canyon (Bay of Biscay, NE Atlantic). Deep- Sea Research II Top Stud Oceanography, 46, 2309-2329.

Sprung, M., 1994. High larval abundance in the Ria Formosaa lagoon in southern Portugal-methodological or local effects? Fournal of Plankton Research, 16, 151-160.

Trush, S.F., Hewitt, J.E., Cummings, V.J. \& Dayton, P.K., 1995. The impact of habitat disturbance by scallop dredging on marine benthic communities: what can be predicted from Author the results of experiments? Marine Ecology Progress Series, 129, $141-150$

Tuck, I., Ball, B. \& Schroeder, A., 1998. Comparison of undis- vol. no.? trubed and disturbed areas. In The effects of different types of $\mathrm{col}^{2}$ fisheries on the North Sea and Irish Sea benthic ecosystems (ed. H.J. publiLindeboom and S.J. de Groot). Nioz-Rapport.

Warwick, R.M., 1988. Analysis of community atributes of the ${ }_{\text {span? }}^{\text {page }}$ macrobenthos of Frierfjord \Langesundfjord at taxonomic levels higher than species. Marine Ecology Progress Series, 46, 167-170.

Warwick, R.M., 1993. Environmental impact studies on marine communities: pragmatical considerations. Australian Fournal of Ecology, 18, 63-80.

Warwick, R.M., Platt, H.M., Glarke, K.R., Agard, J. \& Gobin, G., 1990. Analysis of macrobenthic and meiobenthic community structure in relation to pollution and disturbance in Hamilton harbour, Bermuda. Journal of Experimental Marine Biology and Ecology, 138, 119-142.

Witbaard, R. \& Klein, R., 1994. Long-term trends on the effects of the southern North Sea beamtrawl fishery on the bivalve mollusc Artica islandica L. (Mollusca, bivalvia). ICES Journal of Marine Science, 51, 99-105. 